\title{
Performing Sanctuary
}

\author{
Rebecca M. Schreiber
}

\begin{abstract}
This article examines how Central American migrant and refugee youth imagine forms of sanctuary through collaborative artwork as part of a series of Arte Urgente (Urgent Art) workshops led by artist Caleb Duarte. This artwork involved a critical embodiment and reenvisioning of their past and present experiences in the form of performance. In addition, their creation of a symbolic Embassy of the Refugee was an imaginative way of asserting their right to protection. This article examines how members of affected communities have made artistic interventions into public spaces to focus attention on the nation-state as a site of crisis as well as envision autonomous, noninstitutional sanctuary spaces for each other, while also engaging in ongoing practices of solidarity with other displaced people.
\end{abstract}

KEYWORDS: collaboration, embodied performance, migration, protest, refugee, solidarity, sanctuary, social art practice

In the summer of 2018, artist Caleb Duarte collaborated with five students from Guatemala who are of Maya descent and part of Fremont High School's Newcomer Education Support and Transition (N.E.S.T.) program to create an installation and performance. Their installation, Embassy of the Refugee, which was displayed as part of Bay Area Now 8 held at Yerba Buena Center for the Arts (YBCA) in San Francisco, included a 20' x 10' x 18' structure resembling that of a partially built church or house secured by a cement foundation filled with dirt. During the three-hour performance on 7 September 2018, these students, wearing traditional Maya clothes, dug into the dirt "stage" in order to bury themselves. ${ }^{1}$ While this piece makes violence against Maya visible, it also builds on Duarte's previous collaborative artworks in Mexico and the United States that draw from his questioning of the role of institutions that offer protection for migrants and refugees (Jiménez 2018). Similarly, Embassy of the Refugee serves as an intervention in the space of YBCA, an arts center located in San Francisco, one of the first "sanctuary cities" in the United States (Ridgely 2008). In conversation with Vinh Nguyen's article in this issue in which he understands sanctuary as a "problematizing challenge to the state," this article examines how Central American migrants and refugees have made artistic interventions into public spaces to focus attention on the nation-state as a site of crisis as well to envision autonomous, noninstitutional sanctuary spaces for each other, while also engaging in ongoing practices of solidarity with other displaced people.

This article analyzes performances and other artworks created by Central American youth as part of Arte Urgente workshops organized by Duarte and other artists who established E.D.E.L.O.-Migrante, a transnational, multi-sited project in 2013. The first Arte Urgente workshop that I write about took place at La 72, a migrant and refugee safehouse in Tenosique, 
Tabasco. In Walking the Beast (2014), which they performed on the Suchiate River between Guatemala and Mexico, a group of Central American youth used their bodies to make visible how agreements between the United States and Mexico emphasize "free trade" and securitization, rather than protecting migrants and refugees while traveling between Guatemala and Mexico. The performance Embassy of the Refugee at YBCA developed from a series of Arte Urgente workshops led by Duarte with N.E.S.T. students and held at Fremont High School and La Peña Cultural Center (LPCC) between 2016 and 2018. As part of Duarte's workshops with N.E.S.T. students, they created performances in which they staged a response to the structural conditions that compelled them to migrate and have shaped their everyday lives. The performances that the N.E.S.T. students created, including Pink Ladder and Embassy of the Refugee at YBCA, emerged out of a context in which Central American migrants and refugees are "left with only their bodies to resist" in order to "draw attention to the true crises," which include "US intervention and nation-states' long-term unwillingness to enforce human rights protections in the region," as Leisy Abrego has argued (2018, 213). Duarte and members of the Arte Urgente workshop also created a symbolic Embassy of the Refugee (2018) by painting murals around empty lots to mark a safe place for migrants and refugees in a section of Oakland undergoing gentrification. As I argue, creating a symbolic embassy for migrants and refugees within downtown Oakland involved imagining an autonomous space of safety and support for members of these and other communities who have been displaced from and dispossessed of their homes and homelands.

\section{Walking the Beast: Challenging the Regional Immigration Regime}

Much media attention was brought to the spring 2018 "migrant caravan" as it approached the Mexico-United States border, but it should be noted that Central Americans, including many young people who travel on their own, have been fleeing their countries since the early 2010s. During Obama's second term in office there was a vast increase in unaccompanied Central American refugee youth reaching the Mexico-United States border, particularly between 2014 and 2016. In 2016, sixty thousand minors came to the United States, 32 percent of whom were from Guatemala (US Senate 2018). In the 2010s, the largest number of asylees reaching the Mexico-United States border were from countries in Central America, specifically those in the "Northern Triangle" (El Salvador, Guatemala, and Honduras). Many are at risk of or are actual targets of what the authors of a 2014 United Nations High Commissioner for Refugees (UNHCR) report refer to as "organized armed criminal actors" as well as increased violence in their home countries (UNHCR 2014). However, the Obama administration's response to Central American asylum seekers included an emphasis on what it termed "humanitarianism and border enforcement," the latter of which led to the "expedited removal" (removal without a hearing) of thousands of Central Americans, including refugee children (ACLU 2014). Those who were allowed to enter the United States encountered challenges in gaining asylum as they had to establish a well-founded fear of persecution based on one of the protected grounds, which include race, religion, nationality, political opinion, or membership in a social group.

Caleb Duarte started working with Central American refugee youth in a political context in which the United States refused to recognize either the historical or contemporary contexts that produce refugees from Central America. In recent years, the United States has not pursued regional or national frameworks for ensuring international human rights protections in Central America, as recommended by the United Nations Human Rights Council. Instead, governmental agencies focused on developing immigration enforcement with Mexico on its southern border with Guatemala (Gil 2018). In July 2014, as thousands of unaccompanied youth and families 
from the Northern Triangle fled their countries, the United States pressured Mexico to develop Plan Frontera Sur as a means to deport Central Americans at the Mexico-Guatemala border before they could get to the United States. It also increased checkpoints on roads, as well as the construction of "security-belts" along the Mexico-Guatemala border, as well as in Chiapas and Oaxaca, prompting Central Americans to travel through more remote locations. Plan Frontera Sur overwhelmingly increased the number of apprehensions of Central American migrants and asylum seekers at the Guatemala-Mexico border leading to mass deportations and decreasing the number of migrant and asylum-seeking youth reaching the United States (Ybarra 2019).

Duarte's interest in developing social practice art projects with "communities in movement" stemmed from his own life experiences. Although he was born in El Paso, he migrated with his family from Northern Mexico to California. Much of Duarte's work emerged out of E.D.E.L.O. (En Donde Era La Onu or Where the UN Used to Be), an artist-run residency in San Cristóbal de las Casas, Chiapas, with a focus on engaged art practice that he co-founded with Mia Eve Rollow in 2008 (Léger and Tomas 2017). Duarte and Rollow rented a former UN office building after the UN office moved when a hundred Indigenous community members occupied the building in an effort to release political prisoners (Duarte 2017). Their work at E.D.E.L.O. addressed the limitations of international institutions, such as the UN, as Duarte noted that: "We kept that name to challenge institutions and the role that they play" (Jiménez 2018). As part of E.D.E.L.O., Duarte and other artists collaborated with members of displaced Indigenous communities, differently-abled people, street youth, members of autonomous communities, Zapatistas, Central American migrants and refugees, and other groups. In 2013, as part of E.D.E.L.O.-Migrante, Duarte, Rollow, and other artists in Chiapas, including those affiliated with The University of Arts and Sciences in Tuxtla Gutierrez, created the concept of Arte Urgente. As these artists describe, Arte Urgente is "a practice of immediate investigation, developed in response to the cultural, social, personal, and political that occur within its geographical context" ("Arte Urgente," n.d.). They also note that Arte Urgente was intended to be created with local communities and "encourages us to listen to what communities are expressing and turning that into a visible living experience" (E.D.E.L.O. n.d.). Drawing on the initiatives of the Zapatistas, the artists were also interested in people using their bodies as part of public protest and resistance.

In Walking the Beast (2014), Duarte, Rollow, and Indigenous Zoque artist Saúl Kak worked with a group of Central American migrants and refugees near Mexico's southern border on a performance in which they used their bodies as a creative form of protest to make visible the way agreements between the United States and Mexico emphasize "free trade," border externalization, and securitization rather than protecting migrants and refugees. In the workshop, they painted murals, recorded stories, shared meals, and acted out performances based on their recent lived experiences, while waiting for the train-referred to as La bestia (The beast) - that would transport them through Mexico to the United States. As part of a performance that involved crossing the Suchiate River on the border between Mexico and Guatemala by raft, a group of young men painted their bodies bright colors-representing themselves as similar to the commercial goods that move freely across national borders. ${ }^{2}$ Although the piece invoked the capitalistic circulation of commodities, it also challenges forms of border control established by the United States and Mexico as part of Plan Frontera Sur. These public performances were dramatic, and the paint made them more visible as they crossed the river from Guatemala to Mexico, highlighting the ways that they already stand out as Central American refugees in Mexico. Yet at the same time, the paint obscured their identities, representing a form of protection through art as they crossed national boundaries. This piece also narrates the contradictions 
between the ways nation-states constrain people's movements across national borders, which contrasts with the free flow of goods in a river located between two nations.

\section{Pink Ladder: Collective Trajectories}

E.D.E.L.O.-Migrante was a transnational, multi-sited project that also involved Duarte's collaboration with Guatemalan (Maya) refugee youth living in the Bay area as part of a series of Arte Urgente workshops held at Fremont High School and LPCC. Some of these young people were living with family members in California, while others were in foster care waiting for legal proceedings to determine if they would be granted asylum (Jiménez 2018). The name of the workshops was meant to highlight the urgency of this work related to the conditions experienced by these young refugees who face life or death decisions. It also speaks to the context in which they produced this artwork, while waiting to find out if they would be able to stay in the United States or be forced to return to Guatemala where they would likely experience violence as well as hunger and poverty. Many of these young people were originally from a municipality located in Todos Santos Cuchumatán in Huehuetenango, in the western section of Guatemala that borders Mexico, which send more migrants to the United States than any other parts of Guatemala.

During the workshops, students had the opportunity to create art in different media, and develop performances about their experiences. According to Duarte, most of the participating youth were from a small village and found the experience of living in Oakland overwhelming. Their art-making practices were based on those experiences, as well as in response to their own history being ignored by what they learned in school in Guatemala. In one of the early workshops, the participating youth created performances that involved walking through Berkeley wearing traditional Maya dress or "self-made" Maya masks in the Fremont BART station to assert their identity in spaces where they are not recognized for who they are or their experiences as Indigenous peoples (Duarte 2016). The students also created an "Embassy of the Central American Refugee" at LPCC, and in doing so imagined an autonomous form of sanctuary practice that can be distinguished from those created by and/or within state or international institutions. In the workshops that took place within the space of the fictional embassy, students wrote about their experiences leaving home, traveling through Mexico to the United States, crossing the Mexico-United States border, being placed in detention centers, being released to family members or put into foster care, and living in the Bay area.

Duarte's emphasis on performance within these workshops involved a critical embodiment and reimagining of the students' past experiences. In the 2017 workshop, participants decided to create sculptural performances that Duarte suggests were a means "to use objects of familiarity, of travel, of hope, and to revisit ... aspects of migration in a theatrical form" (Duarte 2016). In preparing for the performance, the students built an exaggerated 30-foot ladder. The meaning of the ladder was significant to them as it resonated with some of their experiences, such as climbing over the Mexico-United States border wall and being fearful about falling from being too high. Eric, one member of the N.E.S.T. Program, told journalist Sarah Burke about the role of the ladder as part of his experience journeying to the United States:

Eric recalls being questioned by Mexican border police when leaving Guatemala, unsuccessfully attempting to convince them that he was from Oaxaca and traveling in search of work, then narrowly escaping detainment by staying on the bus when they sent him back to grab his bag. Things got easier, he says, once he made it to the safe house in Tijuana, where he tried a burrito for the first time. Two days later, he waited for the border patrol to pass, then used a massive aluminum ladder to surmount the wall into the United States. But he hurt his leg 
on the way down, he recalls, and five minutes into walking through the desert, he looked up from the hot ground to find five border patrol officers surrounding him. After 23 days at a detention center in San Diego, he says, he was finally able to board a flight to San Francisco to meet his uncle and settle in Fremont. (Burke 2017)

The sequence of events described by Eric highlights the way young migrants have to act, to perform, and to consciously play to a variety of specific audiences starting from the time they leave home. In addition to Eric's experience with the ladder, it was also significant to the other students as well as it was a group decision to create a "sculptural performance" involving this object. Duarte noted in an interview that in addition to the literal significance of the ladder, it also had more metaphorical meanings, such as striving for success, which relates to one of the reasons why youth from Guatemala travel to the United States-to improve their lives and those of their family members (Duarte 2018b). Once they built the ladder, they started to walk with it around their school and neighborhood in Oakland, which brought attention to their presence and provoked questions from onlookers, such as "what are they trying to climb?" (Duarte 2018b).

After "performing" their piece in more familiar areas, they decided to enact it in a setting that was further removed from their school and neighborhood. As part of a performance, which took place in June 2017 at the Malcolm X Jazz Festival in East Oakland, the N.E.S.T. students held the 30-foot ladder horizontally while maneuvering through the crowd. Although the students started out blending into the crowd, once they began the performance they stood out in large part by "demanding space" (Burke 2017). During their performance, their movement in the space-as they walked with the ladder-required others to move as well. Their movement was thus not only symbolic of their migratory experience but also the assertion of their presence in the context of the United States. As the performers ambled around the Jazz Festival with the ladder, they shaped the space and the crowd. Here they used their bodies to make an intervention in public space alongside an object that represented their aspirations and their vulnerabilities. As Sarah Burke described, this piece was in many ways about how a group of Guatemalan (Maya) teens were "attempting to clear a path of survival in their new home together" (Burke 2017). In an interview, Duarte mentioned that while the performance was enjoyable for the participants, it was also meaningful to them as well. Although the performance attempted to ignite a public response to engage the public, its meaning was open to interpretation by the viewers. The Pink Ladder piece narrated the way the students attempted to collectively navigate around a new city. This performance (and others) also involved a negotiation between their bodies and those of other residents in Bay area cities.

\section{The Embassy of the Refuge: Creating a "Sanctuary" Zone in a Sanctuary City}

The following year-in the spring of 2018-Duarte and some members of the Arte Urgente workshop created the Embassy of the Refugee project, a series of works that included a grouping of murals located in downtown Oakland as part of the Bay Area Mural Festival. ${ }^{3}$ The artists painted these murals around two sides of an empty lot as a means to imagine an Embassy of the Refugee in downtown Oakland to mark a symbolic space for migrants and refugees during the so-called migrant crisis in a section of the city that was undergoing gentrification. The Embassy was situated near construction sites in Oakland where high-rise buildings were being developed for wealthy residents of the city. This art project thus involved repurposing space from that intended for the elite to those who have been displaced.

Referencing their work from the previous year, the N.E.S.T. students included a painting of themselves performing Pink Ladder on a mural section as part of their project to establish this 
space for migrants and refugees. Here the students incorporated elements of their performance representing their experiences onto the mural that formed a wall of the Embassy of the Refugee. The representation of their embodied performance on this section of the mural, in which they used their bodies to assert their presence and dramatize elements of their experiences, appeared along with the statement seguimos en pie (we are still standing) or literally "we remain on [our] feet." These words linked the act of walking with mobility and migration and speaks to the resilience of these youth.

According to Duarte, Embassy of the Refugee was also a way to connect to other movements, including those championed by displaced Aboriginal peoples in Australia, and acknowledge the dispossession of other Indigenous peoples within the spaces that the Embassy occupied (Duarte 2018c, 2020). This work was inspired by Aboriginal artist Richard Bell's Aboriginal Tent Embassy (2013), which was a tribute to the work of Aboriginal activists in Australia who erected an "Aboriginal Tent Embassy" for displaced Indigenous peoples in Canberra, Australia, in 1972. Although their aims were different, the construction of the Embassy of the Refugee in downtown Oakland also delegitimizes the validity of the US settler state that refuses to acknowledge its role in destabilizing governments within Central America and thus in creating the present-day contexts that refugees are fleeing. In a sense, the Embassy functioned as a "sanctuary" or "solidarity" zone for non-status migrants, which as Harsha Walia explains, "take power away from the state because their very existence represents nonparticipation in and subversion of an exclusionary apartheid system of citizenship" (Walia 2013, 113). The Embassy of the Refugee thus imagines a space for those displaced by the US settler state's foreign policies, which produces migrants and refugees. As Duarte noted, in a context where refugees have little political or economic power, the Embassy functioned as a platform where discussion can begin about what the possibilities are for creating better contexts for migrants and refugees (Duarte 2018c).

\section{Conclusion}

Caleb Duarte's collaborative art projects with Central American youth parallel political acts in which Central American refugees "use their bodies to respond to and make visible crises of the state," as Leisy Abrego has described $(2018,214)$. While Abrego is referring to a hunger strike by Central American asylum seekers within a detention center, the Central American youth were part of their own creative artworks, including Walking the Beast, Pink Ladder, and Embassy of the Refugee. These works were created in a moment in which Central American migrant and refugee youth in the United States had little power to assert their rights as a result of what Maritza Cárdenas describes as their "legal unrecognition" by the state (Cárdenas 2018). In response, some migrants and refugees chose to place themselves in sanctuary as a form of protection against deportation and to challenge their "legal unrecognition."

In creating the Embassy of the Refugee, the N.E.S.T. students involved in the Arte Urgente workshops symbolically appropriate the authority of the US settler state, presenting alternatives to its denial of asylum to large numbers of migrants and refugees, which itself creates a crisis and violates both domestic and international law. In locating the Embassy of the Refugee in downtown Oakland, they not only envisioned an autonomous space for themselves, but also created solidarity with other communities by making connections between their own need for protection and for those who need a place to live. As such, the Embassy of the Refugee demonstrates how "art can enact small-scale resistances against the status quo in the social domain" (Bal and Hernández-Navarro 2011, 9). As Duarte states about his methods of working with communities on projects such as the Embassy of the Refugee, "It is a part of an investigation into how art . . can take 
the supposed role of such institutional bodies ... to serve as a tool for imagining alternatives to a harmful and violent system that we do not have to accept" (Jiménez 2018). The Embassy of the Refugee directs attention to the US settler state for its emphasis on bordered exclusion as well as its failure to address the real causes of migration or to offer meaningful solutions. The Embassy of the Refugee was an extension of the Arte Urgente workshops, which included the N.E.S.T. students' sculptural performances that narrated their experiences as asylum seekers. Further, in imagining a fictionalized state agency for refugees, participants in the workshops not only challenge the US settler state's rhetoric of inclusion and exclusion but also envision what solidarity with and accountability toward Central American and other asylum seekers might look like.

\section{ACKNOWLEDGMENTS}

I would like to thank the editors of Migration and Society, the anonymous reviewers, as well as the organizers and participants in the Stakes of Sanctuary workshop for their comments and feedback. I am grateful to Caleb Duarte for many conversations we have had about the artwork featured in this article. I would also like to acknowledge members of the UNM Sanctuary Working Group as well as A. Naomi Paik and Jason Ruiz for our collaborative work co-editing "Radical Histories of Sanctuary" (Radical History Review 135, October 2019).

REBeCCA M. SCHREIBER is a Professor of American Studies at University of New Mexico. Her research focuses on issues of migration between the United States and Mexico and considers relations to place, identity, and dislocation through forms of visual culture. She is the author of The Undocumented Everyday: Migrant Lives and the Politics of Visibility (UMN Press, 2018), and Cold War Exiles in Mexico: U.S. Dissidents and the Culture of Critical Resistance (UMN Press, 2008). She also co-edited "Radical Histories of Sanctuary," an issue of Radical History Review 135 (October 2019) with A. Naomi Paik and Jason Ruiz. E-mail: rschreib@unm.edu

\section{NOTES}

1. Caleb Duarte, "Bay Area Now 8 at Yerba Buena Center for the Arts." 13 October 2018. http://www .calebduarte.org/bay-area-now-8/4594453543.

2. Edelo-Migrante, "Walking the Beast." 2019. http://www.calebduarte.org/chasing-the-beast $/ 458743$ 1571 (accessed 31 January 2021).

3. Caleb Duarte, "Embassy of the Refugee." 2019. http://www.calebduarte.org/embassy/4594227569 (accessed 31 January 2021).

\section{REFERENCES}

Abrego, Leisy J. 2018. "Central American Refugees Reveal the Crisis of the State." In The Oxford Handbook of Migration Crises, ed. Cecilia Menjívar, Marie Ruiz, and Immanuel Ness, 213-228. New York: Oxford University Press.

ACLU Immigrants' Rights Project. 2014. “The Rights of Children in the Immigration Process," July 1. https://www.aclu.org/sites/default/files/assets/aclu_irp_legal_backgrounder_on_children_july_ 2014_final.pdf. 
Bal, Mieke, and Miguel Hernández-Navarro. 2011. "Introduction." In Art and Visibility in Migratory Culture: Conflict, Resistance and Agency, ed. Mieke Bal and Miguel Hernández-Navarro, 9-20. Amsterdam: Rodopi.

Burke, Sarah. 2017. "Culture Cue: On Being Young, Alone, and Crossing Into the United States." KQED, 8 June. https://www.kqed.org/arts/13375958/on-being-young-alone-and-crossing-into-the-unitedstates.

Cárdenas, Maritza E. 2018. Constituting Central American-Americans: Transnational Identities and the Politics of Dislocation. New Brunswick, NJ: Rutgers University Press.

Duarte, Caleb. 2016. "Urgent Art-Covering Our Guis in Order to Become Visible." [In Spanish.] Caleb Duarte's Blog, 24 February. http://www.calebduarte.org/blog/4591348145.

Duarte, Caleb. 2017. "Interview with Caleb Duarte of E.D.E.L.O. Residencia." By Raquel de Anda. In Collective Situations: Readings in Contemporary Latin American Art, 1995-2010, ed. Bill Kelley Jr. and Grant H. Kester, 43-57. Durham, NC: Duke University Press.

Duarte, Caleb. 2018a. Instagram photo, summer. https://www.instagram.com/caleb_arte_/.

Duarte, Caleb. 2018b. Telephone conversation with Rebecca M. Schreiber. January.

Duarte, Caleb. 2018c. Telephone conversation with Rebecca M. Schreiber. September.

Duarte, Caleb. 2020. Email correspondence with Rebecca M. Schreiber. June.

Duate, Caleb. n.d. "Arte Urgente," calebduarte.org, http://www.calebduarte.org/arte-urgente/4578612350.

E.D.E.L.O. n.d. "Historia." http://www.edelo.org/historia/4542117859 (accessed 16 July 2020).

Foley, Gary, Andrew Schaap, and Edwina Howell, eds. 2014. The Aboriginal Tent Embassy: Sovereignty, Black Power, Land Rights and the State. Abington: Routledge.

García, María Cristina. 2006. Seeking Refuge: Central American Migration to Mexico, the United States, and Canada. Berkeley: University of California Press.

García, María Cristina. 2017. The Refugee Challenge in Post-Cold War America. New York: Oxford University Press.

Gil, Oscar. 2018. "From Stateless to Citizen: Indigenous Guatemalan Refugees in Mexico." Emisférica 14 (1). https://hemisphericinstitute.org/en/emisferica-14-1-expulsion/14-1-dossier/from-statelessto-citizen-Indigenous-guatemalan-refugees-in-mexico.html.

Heidbrink, Lauren. 2020. Migranthood: Youth in a New Era of Deportation. Stanford, CA: Stanford University Press.

Jiménez, Elissa. 2018. "Chicano's Collaborative Art Projects Challenge Institutions that Claim to Offer Sanctuary." El Tecolote, 4 October. http://eltecolote.org/content/en/arts_culture/chicanos-colla borative-art-projects-challenge-institutions-that-claim-to-offer-sanctuary/.

Léger, Marc James, and David Tomas. 2017. "Preface." In Zapantera Negra: An Artistic Encounter between Black Panthers and Zapatistas, ed. Marc James Léger and David Tomas, with Emory Douglas, Rigo 23, E.D.E.L.O. (Caleb Duarte and Mia Eve Rollow), and Saúl Kak, iii-iv. Brooklyn: Common Notions.

Ridgely, Jennifer. 2008. "Cities of Refuge: Immigration Enforcement, Police, and the Insurgent Genealogies of Citizenship in US Sanctuary Cities.” Urban Geography 29 (1): 53-77. https://www.tandfon line.com/doi/abs/10.2747/0272-3638.29.1.53.

Office of the United Nations High Commissioner for Refugees (UNHCR). 2014. "Children on the Run: Unaccompanied Children Leaving Central America and Mexico in the Need for International Protection." UNHCR, 13 March. https://www.unhcr.org/56fc266f4.html.

United States Senate, Permanent Subcommittee on Investigations, Committee on Homeland Security and Governmental Affairs. 2018. Oversight of the Care of Unaccompanied Alien Children. Staff report to the United States Senate, Permanent Subcommittee on Investigations, Committee on Homeland Security and Governmental Affairs. 15 August. https://www.hsgac.senate.gov/imo/ media/doc/2018.08.15\%20PSI\%20Report\%20-\%20Oversight\%20of\%20the\%20Care\%20of\%20 UACs\%20-\%20FINAL.pdf.

Walia, Harsha. 2013. Undoing Border Imperialism. Chico, CA: AK Press.

Ybarra, Megan. 2019. “'We Are Not Ignorant': Transnational Migrants' Experiences of Racialized Securitization." Society and Space 37 (2): 197-215. 